\title{
Efficacies of bactericidal Justicia gendarussa extract inhibiting protein synthesis against methicilin resistant staphylococcus aureus
}

\author{
D. Kowsalya ${ }^{1}$, S. Sankaranarayanan ${ }^{2}$ \\ ${ }^{I}$ Department of Biochemistry, Muthayammal college of Arts \&Science,India) \\ ${ }_{2}^{2}$ Managing director, Gloris Biomed research centre (p) Ltd, India)
}

\begin{abstract}
Bacterial infection is one of the most serious global health issues in 21st century .The rise in antibiotic-resistant microorganisms in recent years has led to an increasing search for new antibiotics. Plant secondary metabolites have been used for centuries in traditional medicines and therefore represent a source of potentially active compounds. Justicia gendarussa is reputed for its beneficial effects in Respiratory disorders like cough, cold, bronchitis, throat infections, pulmonary infections and allergic disorders like bronchial asthma.The bacterial diseases can be attributed to Staphylococcus Aureus can be controlled by the extract of Justicia gendarussa extract.
\end{abstract}

Key Words: Bacterial infection,Justicia gendarussa,secondary metabolites,Traditional medicine

\section{Introduction}

Bacterial infection is one of the most serious global health issues in 21st century (Morris and Masterton, 2002). Burn patients are at high risk for nosocomial infections due to multi-resistant bacterial species and a high proportion of which was due to Gram-negative organisms (Moore, 1999). Bacterial colonization of burned and devitalized tissue is inevitable and invasive bacterial infection is still one of the major problems in the treatment of burn victims. Antimicrobial resistance settings have failed to address this essential aspect of drug usage (Monnet et al., 1998). There are a number of clinically efficacious antibiotics becoming less effective due to the development of resistance. The emergence of bacterial resistance to antibiotic is a major health problem and therefore, it is critical to develop new antibiotics with novel mechanism of action to overcome these problems (Wang et al., 2003).

The great interest in the use and importance of Indian medicinal plants by the World Health Organisation in many developing countries has led to intensified efforts on the documentation of ethnomedical data of medicinal plants (Dhar et al., 1968; Waller, 1993; Perumal Samy and Patricraja, 1996). It is a necessity from the scientific point of view, to establish a rational relationship between chemical, biological and therapeutical activities of folklore medicine (Gentry, 1993).

Natural products have been used for thousands of years in folk medicine and recommended for a wide range of ailments. Plants have been the traditional source of raw materials for medicines. A rich heritage of knowledge on preventive and curative medicines was available in ancient scholastic work included in the Atharva veda, Charaka, Sushruta, etc. An estimate suggests that about 13,000 plant species worldwide are known to have use as drugs. These constitute indispensable components of the traditional medicine practiced worldwide due to the low cost, easy access and ancestral experience (Martin-Bettolo, 1980). Biologically active compounds from natural sources has always been of great interest to scientists working on infectious diseases. In recent years there has been a growing interest to evaluate plants possessing antibacterial activity for various diseases (Clark and Hufford, 1993). A number of studies have been reported, dealing with antimicrobial screening of extracts of medicinal plants (Malcom and Sofowora, 1969; Bhakuni et al., 1974; Taniguchi et al., 1978; Moskalenko, 1986; Brantner and Grein, 1994; Grosnenor et al., 1995; Perumal Samy and Ignacimuthu, 1997).

The trend of using natural products has increased and the active plant extracts are frequently screened for new drug discoveries and for the presence of antimicrobials (Das.S, et al 1999). They have been reported to have antibacterial properties against many of microbial organisms (Nadkarni, 1976; Rotimi et al., 1988). For example, a few recent studies have demonstrated the antibacterial activity of traditionally used plants against some selected pathogens from clinical sources (Navarro et al., 1996). The plant kingdom represents a largely unexplored reservoir of biologically active compounds not only as drugs, but also as unique templates that could serve as a starting point for synthetic analogs and an interesting tool that can be applied for a better understanding of biological processes. Folkloric uses are supported by a long history of human experience. Numerous biologically active plants are discovered by evaluation of ethnopharmacological data, and these plants may offer the local population immediately accessible therapeutic products (Aquino et al., 1995). In this 
study, we evaluated the in vitro antibacterial activity of different extract from the leaves of Justicia gendarussa against methicilin resistant Staphylococcus aureus

\title{
2.1 STERILIZATION OF GLASSWARE
}

\section{Materials And Methods}

Glassware were soaked overnight in cleaning solution and washed thoroughly with running tap water. They were then cleaned with detergent solution and rinsed several times with tap water and finally in distilled water and air dried. The glassware and media were sterilized in an autoclave at $15 \mathrm{psi}$ for 20 minutes, at $120^{\circ} \mathrm{C}$

\subsection{MEDIA USED}

\author{
2.2.1. NUTRIENT AGAR PER LITTER/GRAM (NA) \\ Peptone-5.0g \\ Yeast extract- $2.0 \mathrm{~g}$ \\ $\mathrm{NaCl}-5.0 \mathrm{~g}$ \\ Agar-18.0g \\ Distilled water-1000ml \\ pH-7.0
}

\subsubsection{NUTRIENT BROTH PER LITTER/GRAM (NB)}

Peptone-5.0g

Yeast extract- $2.0 \mathrm{~g}$

$\mathrm{NaCl}-5.0 \mathrm{~g}$

Distilled water-1000ml

pH-7.0

\subsubsection{MULLER HILTON AGAR}

Approximate Formula* Per Liter

Beef Extract Powder-2.0 g

Acid Digest of Casein-17.5 g

Starch-1.5 g

Agar-17.0 g

$\mathrm{pH}-7.0$

\subsection{COLLECTION OF PLANT MATERIAL}

Leaves of Justicia gendarussa were collected from Medicinal Plant Garden at Sri Sairam Siddha Medical College and Research Centre, West Tambaram , Chennai 600044.

\subsection{PHYTOCHEMICAL SCREENING TEST OF Justicia gendarussa petal}

\section{Test for Alkaloids}

\section{(A) Dragendroffs reagent:}

$8 \mathrm{~g}$ of bismuth nitrates $\mathrm{Bi}\left(\mathrm{No}_{3}\right)_{3} 5 \mathrm{H}_{2} \mathrm{O}$ was dissolve in $20 \mathrm{ml}$ of $\mathrm{HNo}_{3}$ and $2.72 \mathrm{~g}$ of Potassium iodide in $50 \mathrm{ml}$ of $\mathrm{H}_{2} \mathrm{O}$. These were mixed and allowed to stand for deposition of $\mathrm{KNo}_{3}$ Crystals. The Supernatant was decanted off and made up to $100 \mathrm{ml}$ with distilled water.

Procedure: To $0.05 \mathrm{ml}$ of Punica granatum leaf extract $2 \mathrm{ml}$ of $\mathrm{HCl}$ was added. To this acidic medium $1 \mathrm{ml}$ of dragendroffs reagent was added on, orange or red precipitate produced immediately indicate the presence of alkaloids.

\section{Test of Flavonoids}

\section{A. Alkaline reagent test}

To $1.0 \mathrm{ml}$ of Punica granatum leaf extract a few drops of dilute sodium hydroxide was added. A intense yellow color if produced indicates the presence of flavonoids.

\section{Test for Glycosides}

The Punica granatum leaf extract was hydrolyzed with $\mathrm{HCl}$ for few hours on a water bath and the hydrolysate was subjected to Bornbagers test to the presence of different glycosides.

\section{A. Bornbager's test}

Hydrolysate was treated with chloroform and then the chloroform layer was separated. To this equal quantity of dilute ammonia solution was added. If the ammonia layer acquired the pink color it indicates the presence of glycosides. 


\section{Test for Saponins}

(a) The Punica granatum leaf extract was diluted with $20 \mathrm{ml}$ of distilled water and it was agitated in a graduated cylinder for 15 minutes. The formations of $1 \mathrm{~cm}$ layer of foam shows the presence of saponins

(b) $1 \mathrm{ml}$ of the Punica granatum leaf extract was treated with $1 \%$ lead acetate solutions. Formation of white precipitate indicate the presence of saponins

(c)

V. Test for Tanins

(a) Ferric chloride test

To $1.2 \mathrm{ml}$ of Punica granatum leaf extract few drops of $5 \%$ aqueous $\mathrm{FeCl}_{3}$ solution was added. A violet colour formation indicates the presence of tannins.

\section{Test for Triterpenoids}

\section{(A) Nollers test}

$5 \mathrm{mg}$ of Punica granatum leaf extract was dissolved in $2 \mathrm{ml}$ of $0.01 \%$ anhydrous tannic chloride in pure thionyl chloride. A purple color formed then changed to deep red after few minutes and this indicated the presence of Triterpenoids

\subsection{PARTIAL PURIFICATION OF COMPOUND USING TLC}

The crude dichloromethane extract was spotted on to the pre-coated TLC plates $\left(60 \mathrm{~F}_{2} 54\right)$ and developed with a solvent system of hexane, chloroform and methanol in the ratio of 1:0.5:0.1. The developed plate was viewed under UV $(260 \mathrm{~nm})$. The spots were eluted with chloroform as solvent and used to study its antibacterarial activity.

\subsection{CULTURE COLLECTION AND MAINTENANCE}

The studies of organisms were obtained from CAS in Botany University of Madras Guindy Campus Chennai 600025 Staphylococcus aureus,

\subsubsection{PREPARATION OF CULTURE FOR ANTIBACTERIAL STUDIES}

Twelve hour old bacterial suspension was adjusted to $0.5 \mathrm{OD}$ and $1.0 \mathrm{ml}$ from the above was inoculated into $50 \mathrm{ml}$ of nutrient broth and incubated at $37^{\circ} \mathrm{C}$ in an orbital shaker at $150 \mathrm{rpm}$. To determine the growth rate, culture was removed at $4 \mathrm{~h}$ interval and the growth was monitored by measuring the optical density at $540 \mathrm{~nm}$ in spectrophotometer (Deepvision model $1371 \mathrm{VU} / \mathrm{Vis}$ Spectrophotometer, India). The growth curve was drawn by plotting OD value against the incubation time.

\subsection{ANTIBACTERIAL ACTIVITY OF CRUDE AND ISOLATED COMPOUND}

The antibacterial activity of the crude and purified compound was assayed using the disc diffusion method. Bacteria were grown overnight on Mueller Hinton agar plates, five colonies were suspended in $5 \mathrm{ml}$ of sterile saline $(0.9 \%)$ and the bacterial population in the suspension was adjusted to $\sim 3 \times 10^{8} \mathrm{CFU} / \mathrm{ml}$. A sterile cotton swab was dipped into the suspension and the swab rotated several times with firm pressure on the inside wall of the tube to remove the excess fluid. The swab was used to inoculate the dried surface of MH agar plate by streaking four times over the surface of the agar, rotating the plate approximately by $90^{\circ}$ to ensure an even distribution of the inoculums. The medium was allowed to dry for about 3 min before adding a sterile disc of 9 $\mathrm{mm}$ diameter. Each disc was placed firmly on to the agar to provide uniform contact with the bacteria. Bioactive compound $(50 \mu \mathrm{g})$ was weighed and dissolved in $1 \mathrm{ml}$ of $7 \%$ ethanol. The different concentration of bioactive compound was introduced on to each disc and the control disc received only $7 \%$ ethanol. The plates were incubated at $37^{\circ} \mathrm{C}$ for $24 \mathrm{~h}$ and the inhibition zone was measured and calculated. The experiments were carried out in duplicate three times. The results (mean value, $n=3$ ) were recorded by measuring the zones of growth inhibition surrounding the discs.

\subsection{MINIMAL INHIBITION CONCENTRATIONS (MIC)}

MIC determination was performed using serial broth dilution method. The Crude and isolated compound solution $\left(100 \mu \mathrm{lg} \mathrm{ml}^{-1}, \mathrm{pH}\right.$ 6.1) was serially diluted to different concentrations from 25, 50, 75 and $100 \mu \mathrm{lg} \mathrm{ml}{ }^{-1}$ with NB. Each of the compound dilutions $(5 \mathrm{ml})$ was inoculated with $10 \mu \mathrm{l}$ of the bacterial culture, and then the mixture was incubated at $37^{\circ} \mathrm{C}$ in a test tube on a shaker for 2 days. OD values were taken under $540 \mathrm{~nm}$ and dry weight of Bacterial culture was estimated. 
Data analysis

Bacterial growth was expressed as OD values the dry weight of Bacteria $\left(\mathrm{g} \mathrm{l}^{-1}\right)$. Inhibitory rate of the Justicia gendarussa Crude extract and isolated compound for bacteria was measured as percentage of bacterial growth inhibition, which was calculated by the following formula:

$\%$ growth inhibition of a fungus

BDWof a control bacteria - BDW of a treated sample

= ----------------------------------------------- X 100

BDW of a control bacteria

Where BDW is the mathematical means of the dry weight of bacteria $\left(\mathrm{g} \mathrm{l}^{-1}\right)$ of the bacterial cultures.

\subsection{AGAROSE GEL ELECTROPHORESIS}

REAGENT REQUIRED FOR GEL ELECTROPHORESIS

A. $1.4 \%$ Agarose gel:

nanopure water... $392 \mathrm{ml}$

50X TAE buffer................. $8 \mathrm{ml}$

electrophoresis grade agarose... $5.5 \mathrm{~g}$

Heat to boiling.

Excess gel can be stored at room temperature and remelted for future use. To expedite gel runs, we make 1.61 and divide into $200 \mathrm{ml}$ aliquots in covered, $500 \mathrm{ml}$ erlenmeyer flasks. These can quickly be remelted in a microwave oven as needed.

B. 0.5 M EDTA (pH 8.0):

$\mathrm{mw}=336.2 \mathrm{~g}$ (anhydrous), $354.2 \mathrm{~g}$ (H20), $372.24 \mathrm{~g}$ ( 2 H20) For $500 \mathrm{ml}$, start with approximately $450 \mathrm{ml}$ water and adjust $\mathrm{pH}$ initially with $\mathrm{NaOH}$ pellets. Autoclave.

C. 50X TAE buffer:

Tris-borate............... $242 \mathrm{~g}$

glacial acetic acid........ $57 \mathrm{ml}$

0.5 M EDTA, pH 8.0... $100 \mathrm{ml}$

Dilute to $1 \mathrm{~L}$ with nanopure water

D. Running Buffer (1X TAE):

Dilute 50X TAE to $1 \mathrm{X}$ and use the amount appropriate for the particular gel apparatus.

E. $1 \mathrm{~Kb}$ Ladder $(1 \mu \mathrm{g} / \mathrm{ml})$ :

ladder stock................. $5 \mu \mathrm{l}$

$1 \mathrm{M} \mathrm{NaCl}$.................... $44 \mu \mathrm{l}$

glycerol loading dye $(6 \mathrm{X}) . .7 .5 \mu \mathrm{l}$

We use Life Technologies $1 \mathrm{~Kb}$ Plus DNA Ladder.

F. Glycerol Loading Dye (6X):

bromophenol blue... $0.26 \mathrm{~g}$

glycerol............. $30 \mathrm{ml}$

To $100 \mathrm{ml}$ with nanopure water

G. $1 \mathrm{M} \mathrm{NaCl}$

$\mathrm{mw}=58.44 \mathrm{~g} /$ liter nanopure water

H. Ethidium Bromide:

$10 \mathrm{mg} / \mathrm{ml}$, store in a dark bottle at $4^{\circ} \mathrm{C}$.

\section{Method}

1. Prepare gel solution as outlined under Recipes section.

2. Pour the gel when the agarose has cooled to about $55^{\circ} \mathrm{C}$. Insert the proper comb for the particular gel rig. The gel should be allowed to cool until it has set (it will turn whitish and opaque when ready). The amount of agarose depends on the size of the gel rig. Gels should be fairly thin, approximately $1 / 4$ to $1 / 2$ inch.

3. Carefully remove the comb and place the gel in the gel rig with the wells closest to the cathode (black) end. Cover the gel with $1 \mathrm{X}$ TAE running buffer.

4. Cut a piece of parafilm and place a $5 \mu$ d drop of glycerol loading dye onto the waxy side for each sample to be loaded.

5. Keeping samples on ice, pipette up $5 \mu$ of a sample, wipe the excess oil from the pipette tip with a Kimwipe and add the sample to one of the drops of loading dye.

6. Switch the pipette tip to another pipette set for $10 \mu$ l. Mix the sample and loading dye by filling and emptying the pipette a few times then load the mixture into a well.

7. Continue loading the rest of the samples, placing $5 \mu \mathrm{l}$ of $1 \mathrm{~Kb}$ ladder at both ends of the series of samples and between every 10 samples. 
8. Place the cover on the gel rig and run the samples towards the anode (red) end. For a small gel, we set the power pack to about 60 ma. For a large gel, we use about 120 ma. Milliamperage increases during the run, so check it periodically. Stop the run before the bromophenol blue loading dye front exits the gel.

9. Turn off the power pack, remove the gel and place it in a stain box with $40 \mu$ ethidium bromide: $200 \mathrm{ml} 1 \mathrm{X}$ TAE for approximately 45 minutes. NOTE: Ethidium bromide is light sensitive and must be stored in darkness.

10. Visualize with U.V. light (take proper precautions!) and photograph with a polaroid Photo documentation camera.

11. Dispose of the gel properly. (check to see how your facility handles disposal of ethidium bromide).

\subsection{PROTEIN INHIBITION ACTIVITY OF Justicia gendarussa AGAINST Staphylococcus aureus}

Protein Inhibition activity was performed using serial broth dilution method. The Crude and isolated compound solution (100 $\left.\mu \mathrm{lg} \mathrm{ml}{ }^{-1}, \mathrm{pH} 6.1\right)$ was serially diluted to different concentrations from $25,50,75$ and $100 \mu \mathrm{g} \mathrm{ml}{ }^{-1}$ with NB. Each of the compound dilutions $(5 \mathrm{ml})$ was inoculated with $10 \mu \mathrm{l}$ of the bacterial culture, and then the mixture was incubated at $37^{\circ} \mathrm{C}$ in a test tube on a shaker for $20 \mathrm{hrs}$. Then Extra cellular proteins were estimated by Bradford Method (1976) and SDS PAGE was performed to analyse the inhibition activity in Malecular Mass level.

\subsection{EXTRA CELLULAR PROTEIN ESTIIMATION BY BRADFORD METHOD (1976)} REAGENT

The protein content of the culture filtrate was estimated by the dye binding method of Bradford (1976).

Coomassie Brilliant Blue G-250 (100 mg) was dissolved in $50 \mathrm{ml}$ of ethanol. To this, $100 \mathrm{ml}$ of $85 \%$ $(\mathrm{v} / \mathrm{v})$ phosphoric acid was added and made up to one liter. The concentration in the reagent was $0.01 \%(\mathrm{w} / \mathrm{v})$, CBB G-250, $4.7 \%(\mathrm{v} / \mathrm{v})$, ethanol and $8.5 \%$ (v/v) phosphoric acid.

PROCEDURE

To $1.0 \mathrm{ml}$ of culture filtrate, $5 \mathrm{ml}$ of CBB was added, mixed thoroughly and read at $595 \mathrm{~nm}$ in a Beckman DU-50 Spectrophotometer. The reagent with sterile uninoculated medium served as blank. The amount of protein was calculated using Bovine Serum Albumin Fraction V (Sigma Chemicals Co., USA) as the standard.

\subsection{SODIUM DODECYL SULPHATE-POLYACRYLAMIDE GEL ELECTROPHORESIS (SDS-} PAGE)

SDS-Poly acrylamide gel electrophoresis was performed on slab gel with separating and stacking gels $(10 \& 5 \%$ w/v) by the method of (Laemmli, 1970).

\section{REAGENTS}

STOCK SOLUTIONS

\begin{tabular}{|l|l|}
\hline Solution A & $1.5 \mathrm{M}$ Tris $\mathrm{HCl}$ buffer $(\mathrm{pH} 8.8)$ with $0.4 \%(\mathrm{w} / \mathrm{v}) \mathrm{SDS}$ \\
\hline Solution $\mathrm{B}$ & $0.5 \mathrm{M}$ Tris $\mathrm{HCl}$ buffer $(\mathrm{pH} 6.8)$ with $0.4 \%(\mathrm{w} / \mathrm{v}) \mathrm{SDS}$ \\
\hline Solution $\mathrm{C}$ & $30 \%(\mathrm{w} / \mathrm{v})$ acrylamide with $0.8 \%$ bisacrylamide \\
\hline Solution $\mathrm{D}$ & $1.4 \%$ Ammonium persulphate \\
\hline Solution $\mathrm{E}$ & $1 \% \mathrm{SDS}$ \\
\hline Solution F & $\mathrm{N}, \mathrm{N}, \mathrm{N}, \mathrm{N}$ ' tetramethyl ethylene diamine (TEMED) \\
\hline
\end{tabular}

PREPARATION OF GEL

\begin{tabular}{|l|l|l|l|}
\hline Separating gel [10 \% (w/v)] & Stacking gel [5 \% (w/v)] \\
\hline Solution A & $0.75 \mathrm{ml}$ & Solution B & $0.38 \mathrm{ml}$ \\
\hline Solution C & $2.0 \mathrm{ml}$ & Solution C & $0.5 \mathrm{ml}$ \\
\hline Solution D & $0.3 \mathrm{ml}$ & Solution D & $0.15 \mathrm{ml}$ \\
\hline Solution E & $0.6 \mathrm{ml}$ & Solution E & $0.3 \mathrm{ml}$ \\
\hline Distilled water & $2.6 \mathrm{ml}$ & Distilled water & $1.98 \mathrm{ml}$ \\
\hline Solution F & $0.005 \mathrm{ml}$ & Solution F & $0.005 \mathrm{ml}$ \\
\hline
\end{tabular}

\begin{tabular}{|l|l|l|l|}
\hline \multicolumn{2}{|l|}{ Tank buffer $(\mathrm{pH} \mathrm{8.3)}$} & Sample Buffer \\
\hline Tris & $3.0 \mathrm{~g}$ & Glycerol & $2.0 \mathrm{ml}$ \\
\hline Glycine & $14.4 \mathrm{~g}$ & $\beta$-mercaptoethanol & $1.0 \mathrm{ml}$ \\
\hline SDS & $1.0 \mathrm{~g}$ & $10 \%$ SDS $(w / v)$ & $4.0 \mathrm{ml}$ \\
\hline Distilled water & $1.0 \mathrm{~L}$ & Solution B & $1.7 \mathrm{ml}$ \\
\hline
\end{tabular}


Efficacy of bactericidal Justicia gendarussa extract inhibiting protein synthesis against methicilin

\begin{tabular}{|l|l|l|l|}
\hline & & Bromophenol blue (aqueous) & $0.2 \mathrm{ml}$ \\
\hline & & Distilled water & $0.6 \mathrm{ml}$ \\
\hline
\end{tabular}

\section{PROCEDURE}

The enzyme solution was mixed with an equal volume of sample buffer, boiled in a water bath for 3 min, cooled and added to the wells then the power supply was connected with cathode in the upper tank and anode in the lower tank. Electrophoresis was carried out at room temperature with constant voltage and $20 \mathrm{~mA}$ current supply was maintained until the tracer dye reached $0.5 \mathrm{~cm}$ above the lower end.

STAINING OF SEPARATED PROTEINS

At the end of electrophoresis, gel was removed and stained with silver staining method of Blum et al. (1987). After staining, the gels were stored in $7 \%(\mathrm{v} / \mathrm{v})$ acetic acid.

\section{DETERMINATION OF MOLECULAR MASS}

The molecular mass of the purified Tannase was determined on SDS-PAGE. Purified protein samples were run on SDS-PAGE with concurrent run of standard protein ladders consist $100 \mathrm{kDa}$ (sigma chemicals).After separation, the gels were stained with silver nitrate as described by Blum et al. (1987).

\section{Result}

\subsection{PHYTOCHEMICAL SCREENING OF METHANOL PETAL EXTRACT OF Justicia gendarussa}

The phytochemical screening of the Justicia gendarussa studied showed the presence of flavonoids terpenoids, saponins and tannins (Table -1, Plate-2).

TABLE 1. PHYTOCHEMICAL SCREENING OF METHANOL PETAL EXTRACT OF JUSTICIA GENDARUSSA

\begin{tabular}{|l|l|l|}
\hline S/No. & Constituents & $\begin{array}{l}\text { Methanol petal extract of Justicia } \\
\text { gendarussa }\end{array}$ \\
\hline \multirow{2}{*}{1.} & Alkaloids & + \\
\cline { 2 - 3 } & Mayers reagents & \\
\hline 3. & Tannin & + \\
\cline { 2 - 3 } & $\mathrm{FeCl}_{3}$ test & - \\
\hline \multirow{2}{*}{4.} & Saponins & \\
\cline { 2 - 3 } & Frothing test & - \\
\hline 5. & Terpenoids & \\
\cline { 2 - 3 } & Nollers test & \\
\hline
\end{tabular}

- = Negative (absent)

$+=$ Positive (slightly present)

\subsection{SCREENING OF ANTIBACTERIAL COMPOUND FROM THE LEAF OF Justicia gendarussa BY} TLC

The partially purified dichloromethane extract was loaded on to pre coated TLC $\left(60 \mathrm{~F}_{2} 54\right)$ and it was developed using solvent system in the ratio of 1:0.5:0.1 (hexane, chloroform and methanol) the spot gave out 3 non visible spot from the top to bottom had an RF value $0.15,0.31$ and 0.40 respectively (Plate-4). The colorless spot with the RF value 0.40 fluorescent with UV light in violent color, inhibited the growth of pathogenic bacteria and fungi when compare to other spots. (Table-2, Plate 3)

Table-2 Partial charecterization of methanol petal extract of Justicia gendarussa by TLC

\begin{tabular}{|l|l|l|l|l|}
\hline \multicolumn{6}{|l|}{ Methanol leaf extract of Justicia gendarussa } \\
\hline Component No. & $\begin{array}{l}\text { UV Light } \\
\text { 360nm } \\
\text { Rf value }\end{array}$ & $\begin{array}{l}\text { UV light 240nm } \\
\text { Rf value }\end{array}$ & $\begin{array}{l}\text { Iodine } \\
\text { Rf value }\end{array}$ & $\begin{array}{l}\text { Normal Light } \\
\text { Rf value }\end{array}$ \\
\hline 1 & 0.40 & 0.40 & 0.38 & 0.40 \\
\hline 2 & 0.31 & 0.29 & 0.19 & 0.30 \\
\hline 3 & 0.15 & 0.16 & - & - \\
\hline
\end{tabular}

EFFECT OF CRUDE EXTRACT FROM LEAF OF Justicia gendarussa ON THE GROWTH OF PATHOGENIC BACTERIA BY DISC DIFFUSION METHOD 
The different organic solvent extracts of Justicia gendarussa namely Methanol, Ethyle acetate and Chloroform crude extract at different concentration $(25,50,75$ and $100 \mu \mathrm{l})$ was tested against Staphylococcus aureus. The chloroform extract of Justicia gendarussa exhibited more bactericidal action than other with higher inhibition zone was found at $100 \mu$ l concentration. (Table-3 Fig 1).

TABLE 3. THE ANTIBACTERIAL ACTIVITY OF THE DIFFERENT SOLVENT EXTRACT FROM THE LEAVES OF Justicia gendarussa WERE TESTED AGAINST BACTERIAL PATHOGEN AND EFFECTIVE INHIBITION WAS DETERMINED BY DISC DIFFUSION METHOD.

\begin{tabular}{|c|c|c|c|c|c|}
\hline \multirow{3}{*}{$\begin{array}{l}\text { Different organic } \\
\text { solvent extracts of Justicia } \\
\text { gendarussa }\end{array}$} & \multicolumn{5}{|c|}{$\begin{array}{l}\text { Zone of inhibition }(\mathrm{mm})^{\mathrm{a}} \\
\text { Staphylococcus aureus }\end{array}$} \\
\hline & \multirow{2}{*}{$\begin{array}{l}\text { Positive control } \\
10 \mu \text { Ampicillin }\end{array}$} & \multicolumn{4}{|c|}{ Different concentrations Crude extract $(\mu \mathrm{l})$} \\
\hline & & $25 \mu \mathrm{l}$ & $\mathbf{5 0} \mu \mathrm{l}$ & $75 \mu \mathrm{l}$ & $100 \mu \mathrm{l}$ \\
\hline Methanol & $8 \mathrm{~mm}$ & $10 \mathrm{~mm}$ & $13 \mathrm{~mm}$ & $14.5 \mathrm{~mm}$ & $17 \mathrm{~mm}$ \\
\hline Ethyl acetate & & $07 \mathrm{~mm}$ & $10 \mathrm{~mm}$ & $13 \mathrm{~mm}$ & $16 \mathrm{~mm}$ \\
\hline Chloroform & & $08 \mathrm{~mm}$ & $12 \mathrm{~mm}$ & $16 \mathrm{~mm}$ & $19 \mathrm{~mm}$ \\
\hline
\end{tabular}

a The inhibitory diameter was measured by means of calipers. All the assays were duplicated, and the mean values were recorded.

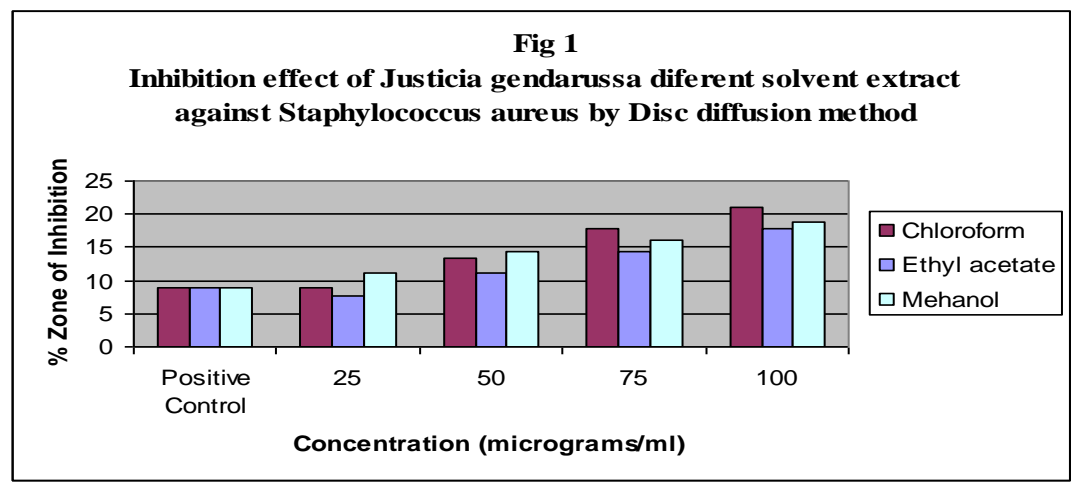

EFFECT OF CRUDE EXTRACT FROM LEAF OF Justicia gendarussa ON THE GROWTH OF ANTIBACTERIAL ACTIVITY BY MINIMUM INHIBITORY CONCENTRATION.

Minimum Inhibitory Concentration (MIC) assays were also performed to determine the antifungal activities of different solvent extract at different time interval. Justicia gendarussa methanolic extract inhibited the growth of Staphylococcus aureus at $100 \mathrm{micro}$ grams $/ \mathrm{ml}$ concentrations. Methanolic inhibited Staphylococcus aureus growth greatly than other solvent extract. 100 micro grams/ml Justicia gendarussa methanolic extract showed higher percentage ranging from 20-50\% of inhibition in Staphylococcus aureus growth phases whereas Chloroform and ethyl acetate extract were inhibited at the \% range of $18-42 \%$ and 18 $44 \%$ respectively. (Fig $2 \mathrm{a}, 2 \mathrm{~b}, 3 \mathrm{a} \& 3 \mathrm{~b}$ ).

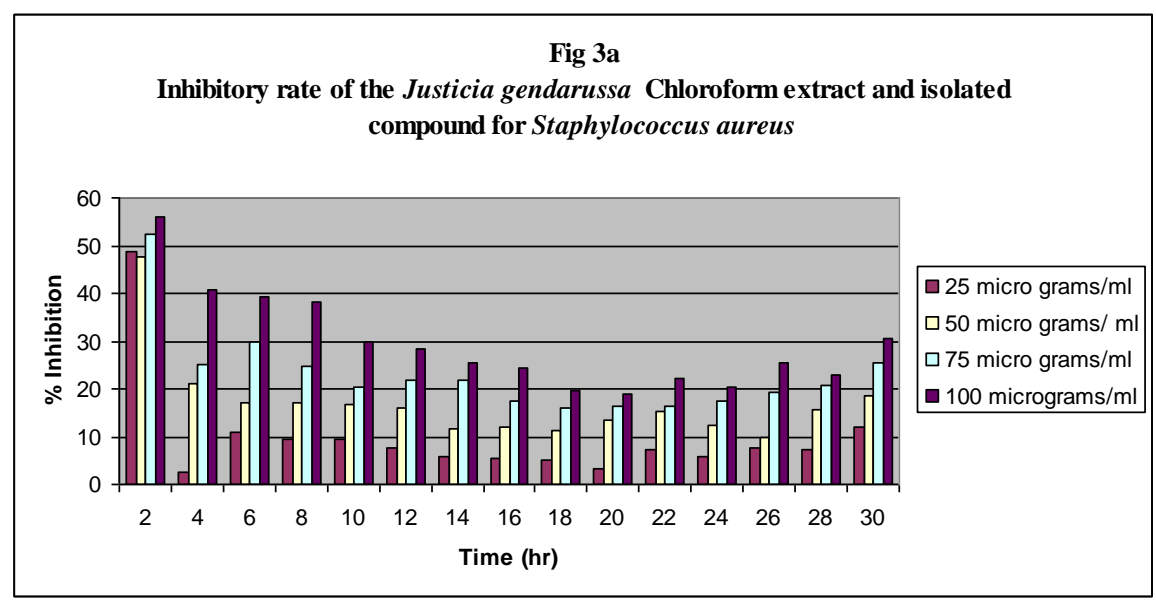



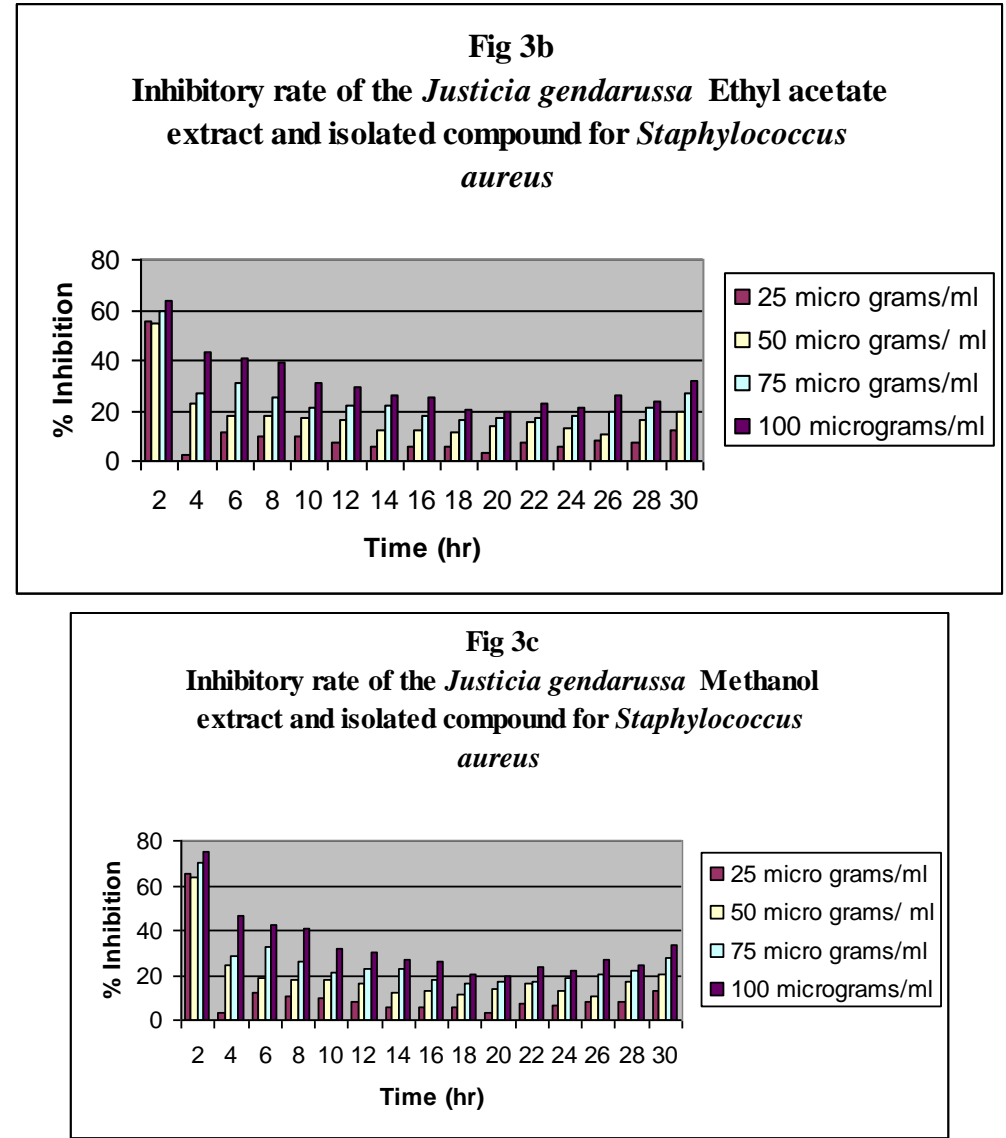

\section{EXTRA CELLULAR PROTEIN ESTIIMATION BY BRADFORD METHOD (1976)}

The Protein inhibition activity at different concentration of Justicia gendarussa methanolic extract was higher in Staphylococcus aureus much higher than other extracts. The highest concentrated Justicia gendarussa methanolic extract (100 micrograms $/ \mathrm{ml})$ showed maximum inhibitory activity in the stationary phase of the Bacterial growth. (Fig 5a, 5b; Plate 5)
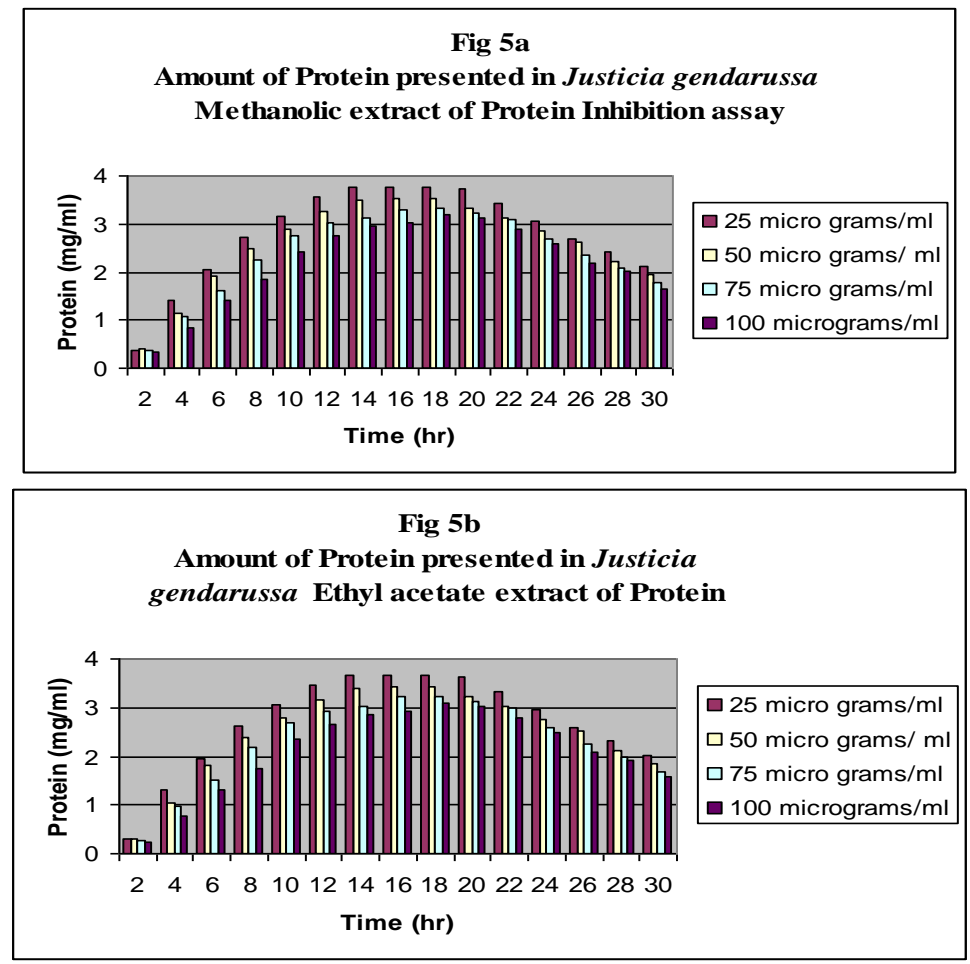


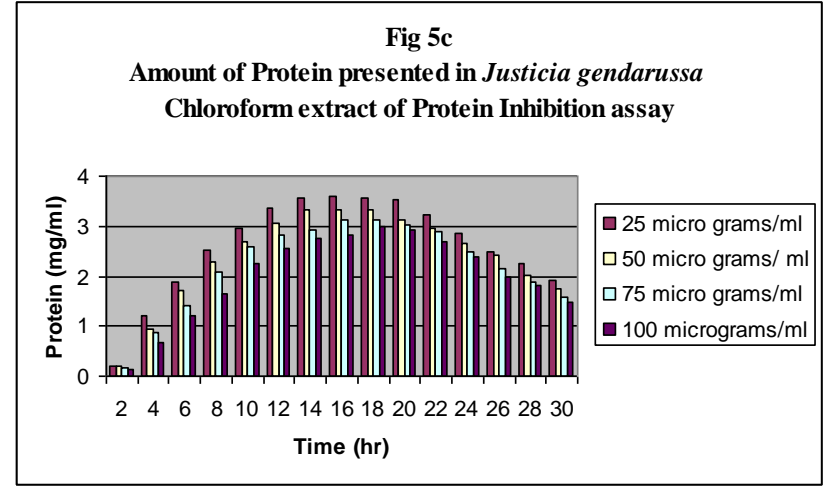

\section{Discussion}

The increase in prevalence of multiple drug resistance has slowed down the development of new synthetic antimicrobial drugs, and has necessitated the search for new antimicrobials from alternative sources. In general, bacteria have the genetic ability to transmit and acquire resistance to drugs used as therapeutic agents. One way to prevent antibiotic resistance is by using new compounds which are not based on the existing synthetic antimicrobial agents (Shah 2005). Phytochemicals from medicinal plants showing antimicrobial activities have the potential of filling this need, because their structures are different from those of the more studied microbial sources, and therefore their mode of action may too very likely differ (Fabricant and Fansworth 2001).

Although antibacterial effects of some medicinal plants were reported previously (Erasto et al. 2004; Martini et al. 2004; Verdrengh et al. 2004; Suzgec et al. 2005), very limited knowledge about mechanisms of their action and spectrum of sensitive bacterial species or strains. In the present investigation demonstrate, sensitivities of defined, commonly used laboratory strain of methicilin resistant bacteria Staphylococcus aureus to flavonoids. To learn about a possible mechanism of antibacterial activity of one of the medicinal plant Justicia gendarussa.

Therefore, the present investigation reveals on the synthesis of DNA, and proteins in Justicia gendarussa extrats treated bacteria. Interestingly, DNA and syntheses were strongly inhibited in methicilin resistant bacteria Staphylococcus aureus relatively shortly (4 h) after the addition of Justicia gendarussa extrats, suggesting that at least one of these processes may be a target for antibacterial activity of Justicia gendarussa extrats. Protein synthesis inhibition, although significant, was delayed relative to that of DNA, indicating that this might be a secondary effect rather than a direct influence of Justicia gendarussa extrats on translation. Snyder and Gillies (2002) has been reported some flavonoids and alkaloids extracts act as inhibitor of DNA topoisomerases type I. The antibacterial activity and acting mechanism of silver nanoparticles (SNPs) on Escherichia coli ATCC 8739 were investigated in this study by analyzing the growth, permeability, and morphology of the bacterial cells following treatment with SNPs. The experimental results indicated $10 \mu \mathrm{g} / \mathrm{ml}$ SNPs could completely inhibit the growth of $107 \mathrm{cfu} / \mathrm{ml} \mathrm{E}$. coli cells in liquid Mueller-Hinton medium. Meanwhile, SNPs resulted in the leakage of reducing sugars and proteins and induced the respiratory chain dehydrogenases into inactive state, suggesting that SNPs were able to destroy the permeability of the bacterial membranes (Wen-Ru et al., 2010)

Although most of these studies were performed using eukaryotic enzymes, when considering evolutionary conservation of the crucial parts of their structures, it is likely that prokaryotic topoisomerases may also be sensitive to Justicia gendarussa. Therefore, this plant phytocompounds extract might influence DNA topology significantly, which should, in turn, lead to strong negative effects on DNA replication. Moreover, it was demonstrated previously that efficiency of transcription of genes coding for rRNA strongly depends on DNA topology, including supercoiling (Hraiky et al. 2000; Rochman et al. 2004). It was speculated previously that genistein-mediated stabilization of the covalent topoisomerase II-DNA cleavage complex may be responsible for moderate inhibition of growth of Staphylococcus aureus strains (Verdrengh et al. 2004).

\section{Conclusion}

Many bacterial diseases can be attributed to Staphylococcus aureus. It appears that Justicia gendarussa methanol extract can inhibit protein synthesis invitro, therefore, they may be used to treat or prevent some bacterial disease caused by Staphlococcus aureus. The present study may lead to the development or synthesis of the new antibacterial drugs from this medicinal plant that is beneficial for bacterial disorder patients..... 


\section{Reference}

[1] Dhar, L.M., Dhar, M.M., Dhawan, N., Mehrotra, B.N., Ray, C., 1968. Indian plants for biological activity: part 1. Indian Journal of Experimental Biology 6, 232-247.

[2] Malcom, S.A., Sofowora, E.A., 1969. Antimicrobial activity of selected Nigerian folk remedies and their constituents plants. Journal of Natural Products 32 (4), 512-517.

[3] Waller, D.P., 1993. Methods in ethnopharmacology. Journal of Ethnopharmacology 38, 189-195.

[4] Snyder RD, Gillies PJ (2002) Evaluation of the clastogenic, DNA intercalative, and topoisomerase II-interactive properties of bioflavonoids in Chinese hamster V79 cells. Environ Mol Mutagen 40:266-276.

[5] Wang, J., Galgoci, A., Kodali Herath, S.K.B., Jayasuriya, H., Dorso, K., Vicente, F., Gonzalez, A., Cully, D., Bramhill, D., Singh, S., 2003. Discovery of a small molecule that inhibits cell division by blocking FtsZ, a novel therapeutic target of antibiotics. Journal of Biological Chemistry 278, 44424-44428.

[6] Verdrengh M, Collins LV, Bergin P, Tarkowski A (2004) Phytoestrogen genistein as an anti-staphylococcal agent. Microbes Infect 6:86-92

[7] Rochman M, Blot N, Dyachenko M, Glaser G, Travers A, Muskhelishvili G (2004) Buffering of stable RNA promoter activity against DNA relaxation requires a far upstream sequence. Mol Microbiol 53:143-152.

[8] Hanawa F, Fokialakis N, Skaltsounis AL. Photo-activated DNA binding and antimicrobial activities of furoquinoline and pyranoquinolone alkaloids from Rutaceae. Planta Med 2004;70:531-5.

[9] Shah PM (2005) The need for new therapeutic agents: what is in pipeline? Clin Microbiol Infect 11:36-42

[10] Wen-Ru Li., Xiao-Bao Xie., Qing-Shan Shi., Hai-Yan Zeng., You-Sheng OU-Yang., Yi-Ben Chen. (2010). Antibacterial activity and mechanism of silver nanoparticles on Escherichia coli Appl Microbiol Biotechnol 85:1115-1122.

[11] Towers FHN, Graham EA, Spenser ID, Abramowski ZA. Phototoxic furanoquinolines of the Rutaceae. Planta Med 1981;41:13642 . 